\title{
Hospitality, Coercion and Peace in Kant
}

\begin{abstract}
In this essay, I discuss Kant's right of hospitality in Toward Perpetual Peace. In the proposed reading, the right of hospitality protects foreigners from the xenophobic practices of the locals, while protecting the locals from the colonial practices of foreigners. The main question guiding this paper is whether hospitality is for Kant a moral injunction calling for a 'humane' treatment of foreigners; or whether it is rather a right senso strictu-namely, one that entails full coercive authority against violations. I argue that once the connections between the dilemma of coercion and the so-called 'institutionalization dilemma' are properly understood, they may be resolved in favor of the first option, namely, coercion. Additionally, by examining the notions of non-centralized coercion and transnational political participation, this paper explores a way to match hospitality's need of coercion with Kant's federalist proposal.
\end{abstract}

Hospitality, as we know, is about what is due to strangers. By its very nature, hospitality lives at the threshold of the polity; it appears at the geographical and political borders, at the fringes, and overlaps between those who share a civil space and those who are alien to it, between resident communities in a given territory and the individuals who show up in that space. Thus, hospitality occupies the space between what is due to persons as members of a specific community, and what is due to them independently of that, merely as human agents. It is precisely this interstitial character of hospitality that opens it up to a decisive ambivalence. Is hospitality a sort of moral obligation that is somehow grounded in our common humanity, or is it a strict right, a coercive norm to which individuals, groups, and-notice-autonomous political entities are subject? This interrogation is the subject of this essay.

\section{The right to hospitality}

That strangers ought not to be treated with hostility is perhaps the least one can accord to the concept of hospitality. That they should be given rights, even political rights, is not, however, what most people in today's nationalistic times would grant. Although Kant said relatively little concerning the nature of hospi-

Efraín Lazos, Universidad Nacional Autónoma de México (UNAM)

Ә OpenAccess. () 2018 Efraín Lazos, published by De Gruyter. (cc)BY-NC-ND This work is licensed under the Creative Commons Attribution-NonCommercial-NoDerivatives 4.0 License. 
tality in general, the right to hospitality is, for him, what defines cosmopolitanism as a world political project ( $\mathrm{ZeF} 8: 349) .{ }^{1}$ Indeed, Kant found a normative void in the relations between foreigners, considered individually, and collective political entities, or receptor states. This void, as he saw it, could not be filled by the traditional law of peoples, centered as it was on the conditions for just war. Kant's focus is not on just any form of hospitality, but on that arising in the clearly asymmetrical situation in which foreign persons individually encounter the authority and power of national states. The philosopher's proposal to the European powers of his time (in his 1795 philosophical masterpiece, Toward Perpetual Peace) was not to have them agree on certain by-laws for waging war and for a new balance of power ( $M d S 6: 352) .^{2}$ Rather, it lay in the idea that peace and hospitality must go together. For Kant, as is well known, perpetual peace is the idea of a peaceful, 'even if not necessarily friendly', community of peoples. ${ }^{3}$ It is precisely this sort of peace that demands the protection of strangers.

Here, however, Kant's text opens itself up to two diverging interpretations as to how exactly the protection of strangers is to be understood. ${ }^{4}$ In one interpretation, his proposal would be a sort of moral call on the powers of Europe of his time not to treat foreign visitors with hostility, and perhaps to grant material assistance (asylum and refuge) to those persons who were displaced by the wars those same powers undertook. In this reading, more generally, this is not a call for the full, legal protection of foreigners, but an attempt at encouraging 'humane' treatment of foreigners in disgrace. ${ }^{5}$ Compliance or non-compliance, if it

1 (See bibliography for abbreviated references) From Francisco de Vitoria to Hugo Grotius, Kant is far from being alone in considering hospitality as some sort of right of strangers. See also: Cavallar 2002.

2 Perhaps the main historical reference of Kant's political intervention in this text is the peace treaty between France and Prussia, known as the Peace of Basel, signed in April 1795. As a result, Prussia lost territory on the left bank of the Rhine, and post-revolutionary France became recognized as a contending party in the power game of the European monarchies of the time. Toward Perpetual Peace was published in Königsberg in August 1795.

3 In contrast to a truce or an armistice, perpetual peace is not conditioned by the satisfaction of certain demands and claims. It is, furthermore, the earthly peace of the living, not the eternal peace of the dead. As an idea of reason, perpetual peace has normative force for individual and collective agents even if the political state of affairs it purports to represent is never fully attainable. See: Anderson-Gold 2010.

4 To my knowledge, Kant's right of hospitality as such has not received the attention it deserves among Kantian scholars, nor among those in the orbit of international law theories and 'humanitarian' studies.

5 Although he does not talk directly about hospitality as such, Jürgen Habermas suggests that Kant is here "forced to rely exclusively on each government's own moral self-binding" (Habermas 1997, p. 118). 
is at all a consideration, is always up to the agents' will. An alternative interpretation takes the call to protect foreigners as a call to design and erect the political institutions that would realize that protection. Such a realization would include encouragement and active recognition of hospitality (e.g., in public programs), as well as a legal expression, with coercive authority over violators.

These two interpretations may also be put in the form of a dilemma. Let us bear in mind that for Kant, although any strict right (jus strictum) is "connected with an authorization to use coercion", sometimes people think of a right in a wider sense (jus latium), such that "no law by which an authorization to use coercion can be determined" ( $M d S$ 6:234). Thus, we see the dilemma of coercion: hospitality is either a right merely in a manner of speaking, so that a violation of it would not carry punishable consequences (it would instead be up to the violating agent's conscience to recognize the damage and to repair it); or it is a strict right, in which case a group of competent judges (together with a whole juridical system) is required to enforce it.

It is not to be assumed that the issues raised by these mutually exclusive readings of Kant can be settled only by textual evidence. This paper aims to show that, despite their historical limits, Kant's thoughts on cosmopolitan rule are fully consistent with the second horn of the dilemma-namely, the idea that hospitality requires foreigners to be legally protected. Furthermore, I argue that the way in which Kant conceives of such legal protection has important lessons to teach us for today's planetary politics of peace. While the role of the right to hospitality may appear on the surface to be merely to enable the legal protection of strangers, the theoretical complexity required to design the institutions that would provide such protection is enormous. While these institutions-the institutions of peace-are meant to be expressions of practices that are in line with categorical morality and republican political ideals, they must inevitably be erected in conditions of intersubjective and collective violence. Here, too, Kant's contribution remains wide and deep. In particular, Kantian hospitality points at a mode of cosmopolitan institution-building that combines full coercive authority with clear respect for the autonomy of peoples. As we shall see, his proposal continues to challenge received ideas about state borders, political power and what is due to strangers.

\section{Neither xenophobia nor colonialism}

In Toward Perpetual Peace, Kant refers to hospitality as a general restriction (Einschränkung) that applies to certain agents within a cosmopolitan right. Those limits combine, at least potentially, the possibility of an immense variety 
of hospitality practices, with principles that cover the treatment of foreigners by public authorities and private citizens. Such principles concern both the objects of hospitality (foreign nationals as well as stateless persons) and the subjects of it (states or political collectives, and individual agents acting in their name). Under the general principle of hospitality, foreigners have the right to appear, to present themselves, in the space of another people and not to be treated with hostility; the receptor state, in turn, is endowed with the power to refuse admission. This power, however, has limits: if the foreign person has fallen into disgrace and presents herself as being in a precarious situation, it is not permissible for the receptor state to reject admission, nor to undertake any action which would increase the person's vulnerability. Put otherwise, the foreign person enjoys certain immunities vis-à-vis the power of the state-not to be treated with hostility, and not to have her vulnerability increased. Although this immunity is limited to her attempt to make contact with the local community, the state in turn has a limited power to expel foreigners, namely, to use violence and force them out. One can see here, in a nutshell, the sense in which a cosmopolitan right may be seen as limited to conditions of hospitality (ZeF 8:357).

Notice that such a restriction has momentous implications in understanding the status of foreign individuals, as well as the nature of state power under a cosmopolitan world order. And notice that, within the framework of Kantian hospitality, the admission of a foreign person is mandatory in those cases (at a physical border such as a river or an ocean) where rejection would likely lead to her demise. Hence, in that case admission is enforced-at least until the circumstances change. Now the principle of hospitality also limits the right of access to a territory, for no foreign individual or collective has an a priori right to establish itself in a foreign territory-unless there is an ex professo treatise or contract. Interestingly, this includes, for Kant, the territories of so-called stateless peoples. In other words, the establishment of foreign colonies in the space of a people is only possible under conditions of mutual consent. Otherwise, the situation is colonialism, and colonialism is evidently opposed to perpetual peace.

At this point, one might already appreciate that hospitality is a dual principle: on the one hand, a people's political autonomy draws a limit for the foreign cosmopolitan traveler; on the other, the autonomy of persons (and presumably, such universal properties of human agency as rationality and dignity) puts a limit on the treatment of foreign persons by state power. Hospitality as a cosmopolitan principle is at once a protection for foreign persons against the xenopho- 
bic practices of the locals, and a protection for the locals against the colonial practices of foreigners. ${ }^{6}$

\section{Two grounds for Kantian hospitality?}

How is this unique principle of a cosmopolitan right justified, according to Kant? One direct, yet complex answer is twofold: by the rational nature of human agency, and by the planetary condition of human life. The former explains the innate right to freedom, which in turn is the basis of any justified claim to a right; the latter explains the contingent fact that, ultimately, we are all neighbors, so that sooner or later we are bound to interact with those who are different from usstrangers. Here we have a combination of two important and complex theories whose details we cannot delve into in much depth here: Kant's moral theory, and his historic-geographic theory of the human species on planet Earth.

Concerning the former, let us briefly recall that, for Kant, our moral duties are not derived from our somewhat incidental, personal bonds with others, even though they apply to our coordinated actions with others. Furthermore, recall that the source of moral bindingness lies only in human rationality. This is not only the capacity for setting oneself certain ends and acting accordingly, but, first and foremost, a capacity for self-governance in acting purposefully: autonomy. In the Doctrine of Right, Kant gives this idea of human agency a particular expression:

Freedom (independence from being constrained by another's choice), insofar as it can coexist with the freedom of every other in accordance with a universal law, is the only original right belonging to every man by virtue of his humanity. (MdS 8:238)

Given that human action, by its own nature, presupposes the capacity of the agent for setting and pursuing ends in a self-governed way, an absence of coercion may be seen as a non-acquired right of all human agents. Coercion-being forced to act for the ends and maxims of others-is a threat to what humans are, namely, creatures capable of autonomy. This is why the right to freedom, understood as an absence of coercion, may be seen as a pre-contractual right-and in this sense, as an innate or non-acquired right. In other words, human agents have the right to freedom just by virtue of being the rational, autonomous beings that they are. Freedom in this sense-lawful non-domination, one may say-is

6 Kleingeld has emphasized the anticolonial aspect of Kant's hospitality in Toward Perpetual Peace, but she appears to miss the anti-xenophobic one. See: Kleingeld 2012, p.72. 
the source of all other (acquired) rights. We may say, then, that our rational nature is the source of all duties and all rights for human agents.

On the other hand, in Kant's work on history, as well as in his lectures on pragmatic anthropology and physical geography, there appears the important notion of a planetary condition: the fact that the surface of the Earth is round needs to be taken into account as an indispensable element in the social arrangement leading to peace-what could be called the 'civil condition', in which social coordination enjoys a maximum of freedom for individual agents, together with a maximum of order or security. In Toward Perpetual Peace, the fact that the extension of the Earth that is adequate for human life is finite, and the fact that humans cannot just indefinitely disperse themselves along the surface of the planet, are grounds for the belief that, sooner or later, we are bound to meet human difference. Hence a possible motto for the planetary condition could be: In the end, we are all neighbors. In the Doctrine of Right (1797), the planetary condition shows up in the idea of an original community of the land (urspüngliche Gemeinschaft der Bodens). This ought not to be understood as a communal possession of the surface of the Earth, but rather as the idea that all humans "are originally (namely, prior to any act of choice that establishes a right) in legitimate possession of land, that is, they have the right to be wherever nature or chance (apart from their will) has placed them...” (MdS $8: 262)^{7}$

In another paper, I suggested that Kantian cosmopolitanism may be understood as an answer to the question of how autonomous agents deal with difference and, ultimately, with violence. ${ }^{8}$ Here, in the discussion of the right to hospitality, one may find another example of such an idea. Freedom-the innate right of human agents to act independently of another's choice-together with the planetary condition, warrants the derivation of the two previously identified aspects of Kant's right of hospitality: anticolonialism and anti-xenophobia. It is clear that, under the planetary condition, there is bound to be interaction, or commercium, among individuals and peoples. Non-domination, in turn, provides the theoretical space for the notion that persons (and groups) need not stay in the same place of residence in which the contingencies of geography and history have put them, and have the non-acquired right to seek the satisfaction of their needs and goals wherever their talents and resources may take them. From the planetary condition and the innate right to freedom, individual persons have the

7 This is sometimes referred to with the expression 'the right to have rights', covering stateless persons and peoples. See: Derrida 2001; Höffe 2006.

8 See: Lazos, “Contextos del cosmopolitismo kantiano”. In: Rivera, F. / Rodríguez Aramayo, R. (Eds.): La filosofía práctica de Kant. México, Bogotá: UNAM / UNC (forthcoming). 
right of visitation, namely, the right to present themselves in the space of another people and not to be treated with hostility. Visitors, in turn, are not therefore authorized to interfere in the sphere of freedom of the hosting people, just as the receiving individuals and collectives are not authorized to reject visitors when such rejection would endanger them. In the latter case, Kant goes as far as saying that receiving states have the duty to accept them as visitors for as long as the external conditions remain, no matter what the material costs are. There is little doubt that Kant is here pointing to what we now know as the right of asylum.

\section{Utopianism and the dilemma of coercion}

In the text of the third definitive article of Toward Perpetual Peace, there seems to be little doubt that the practical principle of hospitality bears the possibility of coercion of certain types of actions. In this, hospitality seems to be like any other right in the narrow sense. It is true, however, that Kant aims at distinguishing a right that is created by a contract (e.g., at a hotel's front desk) from the right of hospitality understood as a right of visitation. It is relatively easy to jump from there to the conclusion that hospitality is a right without the possibility of claiming it [ohne Anspruch]; and from there in turn it is easy to draw the conclusion that hospitality is a right latio sensu, namely, a right without coercion.

There is an answer-or, better put, a glimpse of an answer-in these celebrated and perhaps moving words:

\footnotetext{
Since the (narrower or wider) community of peoples of the earth has now gone so far that a violation of right in one place of the Earth makes itself felt in all others, the idea of a cosmopolitan right is no fantastic and exaggerated way of representing that right; it is, instead, a supplement to the unwritten code of the right of the state as well as that of peoples for the sake of any public rights of human beings and so for perpetual peace. (ZeF 8:360)
}

It must not be forgotten that, in this passage, Kant has already denounced 'the litany of evils' inflicted by European powers on the colonized peoples of America and Africa. This indicates that Kant was not naïve at all in his political-philosophical proposal, and that he clearly recognized asymmetries in power relationships. In one of its aims, the quoted passage is directed at preventing a possible accusation of utopianism in the proposal of cosmopolitan hospitality. Utopianism in this context would consist of imposing the satisfaction of certain goals or duties without giving a clue as to how to reach them. Hence, the Kantian cosmopolitan proposal would be utopian if it proposed a planetary juridical order restricted to hospitality without giving a clue as to how to reach it-especially 
in those situations in which the colonial European powers impose their conditions on the rest of the world. Kant's answer is what could be called the 'political condition' of perpetual peace.

Not only does this political condition refer to the necessary coordination between rational agents (i.e., as legislative members of a kingdom of ends), but also, and above all, to the requisite of building up a world community on the basis of the active political participation of cosmopolitan citizens. In other words, the political condition is composed of the idea of the community of peoples of the Earth, and of the idea of cosmopolitan political participation. For Kant, it is this community of peoples-one in perpetual construction-that may counteract the colonialist and expansionist undertakings of European powers; and it is the existence of this community that allows for a certain historical optimism. Sooner or later (this may be Kant's hidden optimistic reasoning), the right of hospitality will be backed by the possibility of effective coercion by cosmopolitan authorities that are fully legitimized by the community of peoples. This is what would constitute the project of making explicit the implicit code generated by the human right to freedom, and what would complete the project of creating peace through rights.

Kantian optimism in relation to the political condition springs, at least in part, from the conviction that, being more visible for free citizens and self-governed peoples, violations of a public cosmopolitan right will tend to decrease. The extent to which moral indignation in the face of violations of the right of persons and of peoples move the citizens of the world to political participation, and to force their authorities to take an active role in the prevention and punishment of those violations, is the extent to which we may expect the rise of cosmopolitan institutions that promote a peaceful future.

It would be anachronistic to share Kant's optimism on his same historical grounds. He may well have been allowed to be optimistic in his own times, so as to think that extraterritorial political participation (which is the ultimate meaning of the construction of a community of peoples) could attenuate and counteract the unmeasured ambitions of European powers. The political and moral violence of the last century may or may not warrant skepticism vis-à-vis Kant's historical optimism.

In retrospect, the groundbreaking idea that the violation of a right in one part of the world is felt everywhere seems to presuppose that there is no distance between what agents feel (e.g., moral indignation in the face of an atrocity) and what they actually do (i.e., actively participate in the defense and expansion of political freedom for persons and peoples all over the world). Indeed, the innate right to freedom, which dictates the unwritten codex of the rights of humanity, finds its political expression in the republican mode of governance by a people. 
The republic, understood, as Kant does, as collective self-governance, is the mode of social coordination that makes political freedom possible. Political freedom is freedom under external laws. This is then how the idea may be understood that the violation of republican law in one place is felt in all other places: if the right of a single human is injured, the rights of all others are also injuredan instant generalization, through political means, of the effects of an attack on human freedom. Presumably, although this is more conjectural, a successful defense of, or even an advancement in the expansion of human freedom would make itself felt in all places.

If the latter is correct as a sketch, in the details we find important difficulties. The republican mode of social coordination allows the communicability of feeling in the face of a violation of the right to hospitality. This means that only those agents living in and organized under a republic are able have that feeling. The republican feeling, as it may be called, is not of course a natural feeling; it is cultivated and, in part, a product of a revolution or turn in the self conception of persons, of peoples, and of the community of peoples. It becomes evident, then, that for Kant, the republican institutions-with their separation of powers, their principle of publicity and their equalitarian conditions of membership and participation-are the ones that can uphold the principle of hospitality. What, then, is the problem of institutionalization?

Jürgen Habermas has clearly described this situation: at the beginning of the twenty-first century, there are international institutions that enjoy relatively high moral authority and consensus among peoples, but have very scarce capacity of enforcement, while at the same time the logic of the equilibrium of forces prevails among military powers that have a high capacity of enforcement (Borradori 2003). Briefly, the problem of the institutionalization of cosmopolitanism lies in the fact that the possibilities of execution of the right to hospitality are manifestly insufficient vis-à-vis its reiterated and systematic violations by military powers. ${ }^{9}$

It should be obvious that, for Kant, cosmopolitan rule is not meant as a substitute for national rule, but to supplement it. Supplementation, however, leads directly to the institutionalization dilemma: either an expanding federation of republics is the way to reconcile the national and the cosmopolitan orders, and no public law is established; or a world state is instituted, but law is not realized on the basis of the right to freedom (Höffe 2006, p.140). It is well known that Kant,

9 See: Kleingeld 2012, p.86. Habermas is currently an advocate for the 'constitutionalization of international law'; i.e., for "the process of extending democracy and the rule of law beyond national borders” (Habermas 2014, p.5). 
in the second definitive article of Toward Perpetual Peace, adopts the first horn of the dilemma. Thus, federalism is a way of avoiding the need for special cosmopolitan institutions-judges and enforcement apparatuses with transnational jurisdiction. Sometimes this is seen as a sort of concession on Kant's part to political realism or expediency; he was so keenly aware of the barriers to cosmopolitan institution-building erected by national sovereignty, that "he conceived of the cosmopolitan community as a federation of states, not of world-citizens" (Habermas 1997, p. 117).

At this point one can appreciate that the dilemma of coercion arises from the first horn of the institutionalization dilemma. Notice that here, the right to hospitality cannot be enforced, because there is actually no institutional authority to do so. This encourages the following reasoning: since under federalism there are no special cosmopolitan institutions to appeal to in case of a warranted claim to hospitality, hospitality is not enforceable; but if it is not enforceable (the reasoning continues) then it cannot be a strict right, and the cornerstone of cosmopolitanism amounts to nothing more than a moral injunction directed at otherwise unchecked state agents.

Things are, however, more complex. It is evident that from the contingent fact that a certain law cannot be enforced at a given point of time, it does not follow that the law is invalid, nor that it carries no coercion. The link between the two dilemmas-that of coercion and that of institutionalization-hangs fundamentally on how federalism and cosmopolitism are seen to be articulated in Toward Perpetual Peace. While federalism is the answer to the question of lawful interstate relations, cosmopolitanism answers the question of the lawful relations between states and foreign individuals. The usual understanding of that articulation takes states (in the sense of unified peoples under republican laws) to be the basic agents of federalism, and takes cosmopolitanism to be only a supplement of federalism, covering a residue of normativity that was not previously contemplated. Note, however, that if Kant's second definitive article does not solve the question of the legitimacy of interstate coercion, then there will evidently be a pending problem with cosmopolitan coercion in the case of a violation of hospitality. In such a case, the dilemma of coercion insists and persists.

There is another possible understanding of such an articulation-if one takes individual persons to be the basic agents of the process towards perpetual peace. While it is true that federalism grapples with the problem of the legitimacy of coercion among states, in this reading, however, it is federalism that requires cosmopolitism. In other words, the legitimacy of coercion under a federation of republican peoples-a faedum pacificum-depends on the possibility of fully exercising the right to hospitality. On the path to perpetual peace, there would be little sense in declaring interstate relations lawful and peaceful 
when individuals coming from outside the community have no protection from natural or human-caused disasters, and when there is no cosmopolitan restriction to the exploitation and private appropriation of the resources of other peoples. Federal coercion, under this reading, depends on cosmopolitan coercion. In other words, interstate coercion can only be legitimate if the rights of foreigners as such enjoy some sort of warrant.

\section{Non-centralized coercive power and transnational political participation}

My own position is aligned with the latter understanding of the articulation between federalism and cosmopolitanism. The problem of the legitimacy of coercion, under republican conditions, does not get solved once and for all. On the one hand, this is due to the desideratum that the republic may be perfected by learning from its errors; on the other hand, and most importantly, legitimacy is not a totalizing concept referring to a property that something has or has not, once and for all. Kant considers this problem from different angles in his political thought. One may say that legitimacy lies in the simultaneous realization of the idea of self-government in diverse contexts or frameworks. In the context of what is true about the individual agent, legitimacy is present as a process by which a given inhabitant of the Earth becomes a world citizen; in a collective framework, as the transformation of a mere aggregate of persons and groups (sustaining among themselves a war with some degree of intensity) into one republican people; in the context of the community of peoples, by the transformation of permanent interstate war into a cosmopolis-a political and juridical order that is structurally able to admit conflict and dissent, and which potentially includes all the peoples of the Earth. There is a logic of this sort in the three definitive articles of Toward Perpetual Peace-a logic that leads to two quite innovative elements of political philosophy in Kant's time, and are perhaps uncomfortable in our times: the idea of a non-centralized coercive power, and the idea of transnational political participation. I will now take up these two ideas in turn.

The idea of a non-centralized coercive power springs from the break of the republican reductivist maxim according to which many peoples under one law are one people ( $Z e F$ 8:354; MdS 6:343). In a republic, political power (Gewalt) comes from the unified will of the people, so there is a vertical relation (one of subordination) between individual agents-the citizens with political privileges-and the republican power whose purpose is to uphold those privileges. Ver- 
ticality, however, becomes a serious problem for interstate relations. This is one of the reasons why the formula of a Weltrepublik-a republic of republics-is ultimately unable to capture the desired, peaceful relations among peoples. The main problem with that proposal is not that, given its long-term dimensions, a world republic would become unmanageable (scientific and technological developments have already answered to that objection), nor that a world republic would run the risk of becoming a 'heartless despotism', for in any case, that danger is also present at the local, republican level. The deeper problem is that different and diverse unified collective wills cannot transform themselves into one single people. Using the rhetoric of the state of nature that Kant employs to describe situations of intersubjective and interstate violence, we may observe that the analogy between the individual and collective contexts is maintained as to the motivations to coalesce; but the analogy is broken regarding the structure of coercive power. In interstate relations coercion cannot be vertical, for otherwise the unified collective will of each people would disappear.

In my reading, federalism is presented by Kant as a solution to the problem of verticality within the republican mode of political coordination. But verticality is not the only condition under which coercion may occur. As has already been pointed out, Kant was consistent throughout his work in pointing out that the local problem of 'how to administer justice universally' ( $I z E$ ) can only be solved on the condition that interstate relations become lawful, namely, when humanity abandons the planetary state of nature in which violence (intersubjective and among collectivities and peoples) prevails. All forms of despotism belong, in this sense, to a state of nature. This already indicates that Kant does not understand that mode of political power which arises from the self-governance of a people as self-sufficient, nor as absolute. It is not a feat that one lonely people can realize on its own, and it is not a capacity that a collectivity may have or not have, once and for all. Federalism, that surrogate of a world sovereign power, solves the problem of the verticality of coercion among republican peoples, which in the extreme would mean the disappearance of each people; but it does not solve the problem of the legitimacy of coercion. Precisely that, I submit, is the role of the second important idea-transnational political participation.

The notion of transnational political participation is an element of what I have called here the 'political condition', which is an answer to the charge of utopianism in the presentation of cosmopolitan hospitality. The political condition has two mutually related components: the community of peoples, and transnational political participation. The latter may take several forms; in accordance with federalism, however, participation must be horizontal, in conditions of freedom and equality among persons and peoples. This means that political participation, which for Kant is tied up with the feeling of indignation in the face of a 
violation of a right in any part of the world, is independent of the privileges of local political participation. In turn, the formation of a community of peoples must be understood as the process by which coercion is legitimized. Such a process indeed includes an institutional scaffolding-but this does not constitute the whole process. In particular, the sort of political participation that carries with it the formation of world-citizenship is centered on the individual agent, contingently located in a given space and time, and on what she can make for herself-in contrast to what nature has made for her (APS; MdS; ZeF). In other words, the formation of world citizenship belongs to the same process by which a community of peoples is formed: both call into question those impediments to political action that are due to the contingent origins of a person or of a collectivity. This is relatively easy to understand in the context of foreign residents (people of foreign origin residing in a country)-of which there was no lack in Kant's Königsberg-but not so in the context of the participation of foreign nationals (persons and groups from foreign countries living in foreign countries). One should say that the forms that such a political participation could adopt are only subject to speculation if attributed to Kant.

This being the concept of transnational political participation, why would self-governed peoples give up power to it? Firstly, the group of agents involved in the process (the citizens of the republic and the citizens of the world) is potentially one and the same: so the group of people who would give up power and the group of people to whom power is being given is one and the same. Secondly, the citizens would have republican control over local authorities through local institutions and mechanisms, but also over cosmopolitan authorities through planetary institutions and mechanisms. Cosmopolitan authority will be answerable to individual citizens, but also to local authorities; and these in turn will be answerable to cosmopolitan authorities and to their 'own' peoples. In brief, what this means is that doubts concerning horizontal coercive power among peoples may be dispelled by observing that state power, when conceived under republican principles, is neither self-sufficient nor absolute. It ought to respond to the will of the equals, so that it cannot be arbitrarily enforced, for example, on foreign residents and on peoples or individuals in other parts of the world; and it is not self-sufficient since, as we have shown, the legitimacy of vertical republican coercion depends on that of a federation of republics; and, beyond this, they both depend on the horizontal coercion characteristic of a cosmopolitan condition. 


\section{Final remarks}

The charge of utopianism regarding the right to hospitality may be answered in one of two ways: with a story about the institutionalization of the moral and political ideals of cosmopolitanism; or with a story about the source of cosmopolitan coercion. The former responds to the problem of the execution or enforcement of cosmopolitan law, the latter to the problem of the legitimacy of coercion. While it is true that they both involve what I have here called the political condition-that form of social coordination that is characteristic of selfgoverned agents roaming the finite surface of the Earth-it is important not to confuse these two problems.

My claim in this paper may be understood as an attempt to critically evaluate the last paragraph of the third definitive article of Toward Perpetual Peace. I have argued that the right to hospitality is for Kant both an anti-xenophobic and an anti-colonial principle, which carries with it full coercive force. Not only does the right to hospitality stem from the unconditional command not to instrumentalize other agents (where noncompliance is sanctioned by the agent's own moral conscience)-it constitutes a cosmopolitan legal command whose breach brings about systematic and negative consequences for the external freedom of noncomplying agents. So the dilemma of coercion is solved by affirming the first horn (justified coercion of external freedom) and denying the second (a moral reprimand). It may be open to debate what are the proper jurisdictions and overlaps of the institutions involved, but the validity of the right of hospitality demands the possibility of effective coercion.

It is vital to stress here the role of transnational political participation as an element of a global political condition with peaceful intent. This is crucial in order to understand under what conditions coercion of state actions that violate hospitality is justified. It is by virtue of the political condition that the implicit code generated by lawful freedom can be made explicit; and this gives substance to the project of creating peace through rights. That project is, as we saw, inseparable from a multileveled political participation of individuals and collectivities, and is the source of the legitimacy of cosmopolitan coercion of those state actions that contravene the principle of hospitality. As we have seen, interstate coercion under federalism is only legitimate if the rights of foreigners as such have some sort of generalized trans-border warrant.

The other component of the political condition in Kantian cosmopolitanism is the construction of a community of peoples. We might find in Kant some clues for such a construction in a kind of theory of republican political sentiments that, in analogy with aesthetic taste, we hope to share with diverse and distant 
persons and peoples. Republican sentiments-including the feeling of indignation-are an important part of the process of constructing a community of peoples. It is not enough, in such a process, to form groups or organizations with an affinity of interests and relatively independent from state agencies-so-called 'non-governmental organizations'. In every case, and especially when it comes to corporations such as the religious and the military, the public use of one's own reason would have to be upheld if such organizations aspire to be part of the community of peoples.

Finally, let us briefly turn to the question concerning the scope of cosmopolitan authority, and whether it supplements or substitutes national authorities. The key seems to lie in one more sense in which cosmopolitan coercion may be reduced to conditions of hospitality. It is true that, to the extent that republican constitutions incorporate the cosmopolitan protection of foreigners into their principles, the traditional difference between foreign and domestic policies will tend to blur out. So the extent to which national jurisdiction ought to be supplemented by cosmopolitan law depends on the extent to which the local jurisdiction protects foreigners. The idea here is: one clear domain in which national authority needs to be supplemented is the enforcement of the principle of hospitality. That is, even a perfect republic, in which power would be at once disseminated (e.g., in the assembly of free agents) and concentrated (in the united will of the people represented by the sovereign), is not self-sufficient when it comes to protecting the rights of foreigners as such-including undocumented and stateless persons and peoples. Since the treatment of foreigners is the space in which national governments may be most evidently prone to a conflict of political interests, it is precisely there where functioning cosmopolitan institutions are needed.

Beyond interpretive matters, one possible lesson of this essay is that suspicion is commendable in the face of the recurring attempts to bring up to date Kant's historical optimism. If cosmopolitan penal justice (e.g., the International Criminal Court) had full coercive force to process the crimes against humanity that have been committed for the interests and by the state agents of the strongest military power in history, then perhaps Kant's historical optimism could be renewed. In the meantime, it is perhaps advisable to substitute optimism with a sober critique of humanitarian reason. 


\section{Abbreviated References}

In this paper, all references to Immanuel Kant's works are in accordance with the Akademie Ausgabe (AA), Vols. 1-29 of Kants Gesammelte Schriften (Berlin, Leipzig, 1902). References indicate the volume number followed by the page number. Unless otherwise indicated, the English language translations are from the Cambridge Edition of the Works of Immanuel Kant (New York: Cambridge University Press, 1992). The following abbreviations are used throughout this paper.

APS Anthropologie pragmatischer Hinsicht (1798), AA 6:119-333.

IzE Idee zu einer allgemeinen Geschichte in weltbürgerlicher Absicht (1784), AA 8:17-31.

MdS Die Metaphysik der Sitten (1797), AA 6:205-492.

ZeF Zum ewigen Frieden (1795), AA 8:343-386.

\section{Bibliography}

Anderson-Gold, S. (2010): “Kant’s Cosmopolitan Peace”. In: Muchnik, P. (Ed.): Rethinking Kant. Vol. 2, Newcastle: Cambridge Publishers.

Benhabib, S. (2006): “Philosophical Foundations of Cosmopolitan Norms”. In: Post, R. (Ed.): Another Cosmopolitanism. New York: Oxford University Press.

Borradori, G. (2003): “A Dialogue with Jürgen Habermas”. In: Philosophy in a Time of Terror, Dialogues with Jürgen Habermas and Jacques Derrida. Chicago: The University of Chicago

Press.

Cavallar, G. (2002): The Rights of Strangers: Theories of International Hospitality, the Global Community and Political Justice since Vitoria. London: Ashgate.

Cavallar, G. (2015): Kant's Embedded Cosmopolitanism. History, Philosophy and Education for World Citizens. Berlin: De Gruyter.

Derrida, J. (2001): On Cosmopolitanism and Forgiveness (translated by S. Critchley \& R. Kearney). New York: Routledge.

Duque, F. (2006): ¿Hacia la paz perpetua o hacia el terrorismo perpetuo? Madrid: Círculo de Bellas Artes.

Habermas, J. (1997): “Kant's Idea of Perpetual Peace, with the Benefit of Two Hundred Years' Hindsight”. Bohman, J. / Lutz-Bachman, M. (Eds.): Perpetual Peace. Essays on Kant's Cosmopolitan Idea. Cambridge (MA): MIT Press, pp. 113-154.

Habermas, J. (2014): "Plea for a Constitutionalization of International Law". In: Philosophy and Social Criticism, Vol. 40 (1), pp. 5-12.

Höffe, O. (2006): Kant's Cosmopolitan Theory of Law and Peace (translated by A. Newton). New York: Cambridge University Press.

Ion, D. (2012): Kant and International Relations Theory. Cosmopolitan Community-Building. London: Routledge.

Kersing, W. (2004) "Die bürgerliche Verfassung in jedem Staate soll republikanisch sein". In: Höffe, O. (2004) (Ed.): Immanuel Kant: Zum ewigen Frieden. Berlin: Akademie.

Kleingeld, P. (2012): Kant and Cosmopolitanism. The Philosophical Ideal of World Citizenship. New York: Cambridge University Press. 
Kuper, A. (2000): "Rawlsian Global Justice: Beyond The Law of Peoples to a Cosmopolitan Law of Persons”. In: Political Theory, No. 28, pp. 640-674.

Lutz-Bachmann (1997): “Kant's Idea of Peace and a World Republic”. In: Bohman, J. I Lutz-Bachmann, M. (Eds.) (1997): Perpetual Peace. Essays on Kant's Cosmopolitan Idea. Cambridge (MA): MIT Press, pp. 59-78.

Martiarena, O. (2009): La formación del ciudadano del mundo. México: Alia.

Pereda, C. (1996): "Sobre la consigna, 'Hacia la paz perpetuamente”. In: Muguerza, J. / Rodríguez Aramayo, R. / Roldán, C. (Eds.) (1996): La paz y el ideal cosmopolita de la ilustración. A propósito del bicentenario de Hacia la paz perpetua, de Kant. Madrid: Tecnos, pp. 77-100.

Riedel, M. (1981): "Transcendental Politics? Political Legitimacy and the Concept of Civil Society in Kant”. In: Social Research, Vol. 48-3, pp. 588-613.

Roldán, Concha (2011): "Perpetual Peace, Federalism and the Republic of the Spirits: Leibniz Between Saint-Pierre and Kant”. In: Studia Leibnitiana, 43/1, pp. 87-102. Rodríguez Aramayo, R. (1994): "El utopismo ucrónico de la reflexión kantiana sobre la historia”. Preliminary study for: Ideas para una historia universal en clave cosmopolita y otros escritos de filosofía de la historia. Madrid: Tecnos.

Zöller, G. (2015): Res Publica. Plato's Republic in Classical German Philosophy. Hong Kong: The Chinese University Press. 
